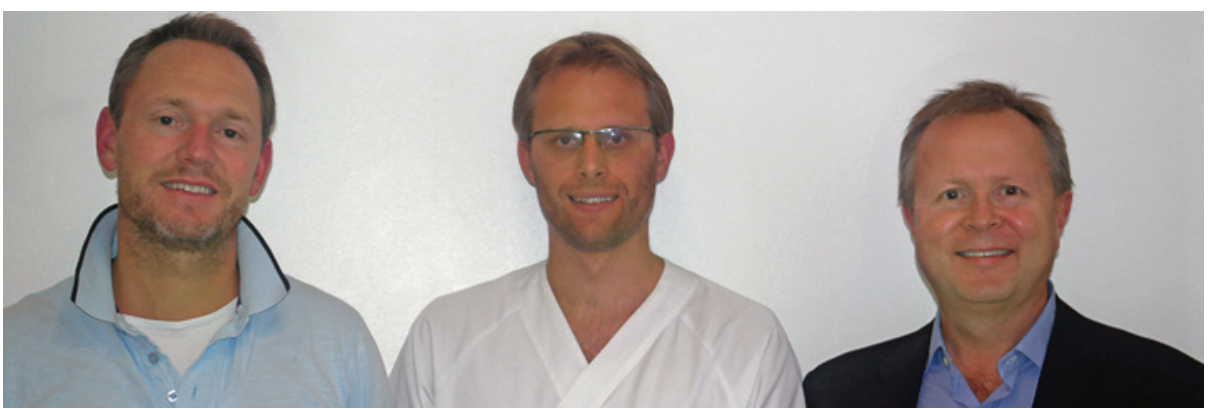

Helge Røsjø, Gunnar Einvik og Torbjørn Omland. Foto: Cardiothoracic Research Group

\section{Kan søvnapné gi myokardskade?}

En norsk studie har påvist høyere konsentrasjon av kardial troponin I i serum ved obstruktiv søvnapné.

Pasienter med obstruktiv søvnapné har økt forekomst av hjertesvikt, men det er usikkert om årsaken til dette er knyttet direkte til sykdommen eller til felles risikofaktorer, som høy alder, kjønn og overvekt. Tidligere studier har ikke funnet noen sammenheng mellom obstruktiv søvnapné og de hjertespesifikke markørene troponin $\mathrm{T}$ eller troponin I, men i disse studiene ble det brukt målemetoder med lavere sensitivitet til konsentrasjonsbestemmelsen av troponin.

Forskere ved Akershus universitetssykehus og Universitetet i Oslo har nylig publisert en studie der blodprøver fra 514 personer i alderen 30-65 år i ble analysert. Deltakerne gjennomgikk polysomnografi, klinisk undersøkelse og samling av blodprøver til biobank i perioden 2006-08. Obstruktiv søvnapné ble påvist hos 229 av deltakerne (1).

I 2013 ble serumprøver undersøkt med dagens mest høysensitive metode for troponinbestemmelse. Troponin I-konsentrasjon i serum var høyere desto mer alvorlig obstruktiv søvnapné deltakeren hadde. Etter statistisk justering for etablerte risikofaktorer for kardiovaskulær sykdom, var det en signifikant sammenheng mellom økt apnéhypopné-indeks og økende troponin I-konsentrasjon $(p=0,006)$.

- Studiens hovedstyrker er det høye antallet deltakere, at deltakerne er rekruttert fra den generelle befolkningen og bruk av høysensitive målemetoder for troponin, sier førsteforfatter og lege Gunnar Einvik. - Metoden kan påvise troponin I-konsentrasjoner hos over $90 \%$ av en normal voksenpopulasjon, sammenliknet med under $50 \%$ ved tidligere høysensitivitetsmetoder. Vi mener derfor at utsagnsverdien av studien er sterkere enn i tidligere negative studier.

- Obstruktiv søvnapné er en hyppig oversett tilstand, og vår studie indikerer at sykdommen i seg selv kan gi direkte affeksjon av myokard. Økt oppmerksomhet om tilstanden og behandling ved etablert søvnapné kan derfor være viktig for å forebygge kardiovaskulær sykdom, sier Einvik.

\section{Forskningsgruppe om søvnapne}

Studien er en del av Akershus Sleep Apnea

Project - ASAP - som er en strategisk satsning ved Akershus universitetssykehus i samarbeid med Universitetet i Oslo. Prosjektet har en epidemiologisk og tverrfaglig tilnærming til problemstillinger knyttet til søvnapné, med bidrag fra både fagene kardiologi, nevrologi, psykiatri, psykosomatikk, øre-nese-hals og helseøkonomi. Eksterne samarbeidspartnere er Søvnsenteret ved Haukeland universitetssykehus, Mayo-klinikken i Rochester, Minnesota, USA og Oslo universitetssykehus, Aker.

Pasientundersøkelsene foregikk hovedsakelig i tidsrommet 2006-08 og omfattet i alt 30000 personer i Akershus, Hedmark og Oppland som fikk tilsendt spørreskjemaer. Fem ph.d.-kandidater har disputert eller levert avhandlinger basert på prosjektet, og 15 artikler er publisert $i$ internasjonale tidsskrifter.

Den omtalte artikkelen er publisert i tidsskriftet Sleep og er skrevet av forskere fra Cardiothoracic Research Group ved Akershus universitetssykehus. Gruppen kombinerer grunnforskning, randomiserte kliniske studier og epidemiologiske studier på store pasientgrupper. Utvikling og testing av klinisk bruk av hjertemarkører er en sentral del. Førsteforfattere er Gunnar Einvik, som er ph.d.-stipendiat og lege, og Helge Røsjø, som er førsteamanuensis og avdelingssjef for forskning ved Medisinsk divisjon. Medforfattere er Anna Randby, Silje Kjeka Namtvedt, Harald Hrubos-Strøm, Jon Brynildsen, Virend Somers og Torbjørn Omland. Sistnevnte er prosjektleder for kardiologidelen av ASAPprosjektet.

\section{Hanne Støre Valeur}

Tidsskriftet

\section{Litteratur}

1. Einvik G, Røsjø H, Randby A et al. Severity of obstructive sleep apnea is associated with cardiac troponin I concentrations in a community-based sample: data from the Akershus Sleep Apnea Project. Sleep 2014; 37: 1111-6, 1116A-1116B.
Ordforklaringer

Obstruktivt søvnapnésyndrom (OSAS): En tilstand der trange forhold i svelget og øvre luftveier gjør at luftpassasjen innsnevres > $70 \%$ eller tettes helt når man sover. Dette bidrar til snorking og pustestopp under søvn, med konsekvenser som redusert søvnkvalitet, tretthet på dagtid og høyt blodtrykk.

Kardial troponin I: Et protein i det kontraktile apparatet til hjertemuskelcellen. Troponin I fra hjertet er immunologisk distinkt fra troponin I i skjelettmuskulatur, og finnes vanligvis bare i ørsmå mengder i blodet. Kronisk økte mengder av dette stoffet i blodet tyder på skade og belastning på hjertemuskulaturen og er forbundet med $ø$ kt risiko for hjertesviktutvikling og fremtidig død.

Myokard: Hjertemuskel. 